\title{
JEKK
}

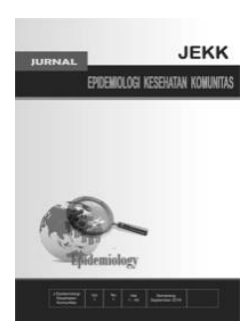

\section{Faktor-Faktor yang Berhubungan dengan Kualitas Hidup Orang dengan HIV/AIDS (ODHA) di Yayasan Sehat Peduli Kasih Kota Semarang}

\author{
Ausy Hawais Monasel, ${ }^{*}$ Henry Setyawan Susanto, ${ }^{* *}$ Sri Yuliawati, ${ }^{* *}$ Dwi Sutiningsih ${ }^{* *}$ \\ *Mahasiswa Peminatan Epidemiologi dan Penyakit Tropik, Fakultas Kesehatan Masyarakat, \\ Universitas Diponegoro, Semarang, \\ ${ }^{* *}$ Bagian Epidemiologi dan Penyakit Tropik, Fakultas Kesehatan Masyarakat, \\ Universitas Diponegoro, Semarang
}

\begin{abstract}
Background: HIV/AIDS is still considered as a deadly and hard to be cured disease by the society and therefore raises negative perceptions towards People Living with HIV/AIDS (PLWHA). These negative perceptions can influence the quality of life of PLWHA, where the worse quality of life that they have, the greater chances for them to develop AIDS. This study aims to analyze the factors associated to the quality of life of PLWHA.

Methods: The population of this study is PLWHA in Semarang City who are currently undergoing ART therapy and are under the assistance of Yayasan Sehat Peduli Kasih. The study was conducted on October - November 2020 towards 70 subjects whom were chosen using the purposive sampling technique. Instrument used for this study was online questionnaires. Data were analyzed with univariate and bivariate analysis using a chi-square test.

Result: The results showed that $54.3 \%$ of the subjects were having poor quality of life. Factors that are associated with the quality of life of PLWHA are income level $(\mathrm{p}=0.009)$, duration of diagnosis $(\mathrm{p}=0.004)$, duration of ART therapy $(\mathrm{p}=0.002)$, level of family support $(\mathrm{p}=0.007)$, level of stigma $(\mathrm{p}<0.001)$ and level of depression $(\mathrm{p}<0.001)$. Meanwhile gender, age, marital status, education level, employment status and the level of medication adherence did not associate with the quality of life of PLWHA.

Conclusion : Based on these results, it is recommended to conduct a comprehensive social activity that is focused on improving the mental health and the quality of life of PLWHA where all patients with any backgrounds could freely participate.
\end{abstract}

Keywords: HIV/AIDS; Quality of Life; People Living with HIV/AIDS.

*Penulis korespondensi, ausyhm@gmail.com 


\section{Pendahuluan}

Human Immunodeficiency Virus (HIV) adalah virus yang menyerang sel CD4 yang bertugas untuk mengatasi infeksi, sehingga jika virus ini sudah masuk ke dalam tubuh maka akan membuat manusia lebih rentan terhadap infeksi dan penyakit lain. Virus ini menular melalui kontak dengan cairan tubuh Orang Dengan HIV/AIDS (ODHA) yang umumnya terjadi saat melakukan hubungan seksual yang tidak aman atau melalui pemakaian jarum suntik bergantian. Tanpa perawatan, virus ini akan terus bereplikasi dan menyebabkan penyakit AIDS (Acquired Immuno Deficiency Syndrome), yaitu tingkatan terakhir dalam infeksi HIV yang timbul ketika sistem imun tubuh semakin melemah. ${ }^{1}$

Berdasarkan UNAIDS pada tahun 2018, terdapat 39,7 juta kasus HIV/AIDS di dunia. ${ }^{2}$ Di Indonesia, pada tahun 2019 terdapat 50.282 kasus baru HIV dan 7.036 kasus baru AIDS. Dalam lima tahun terakhir, Jawa Tengah secara konsisten masuk ke dalam empat besar kasus HIV terbanyak dan menduduki peringkat pertama kasus AIDS terbanyak di Indonesia. Pada tahun 2019, jumlah kasus HIV di Jawa Tengah adalah sebesar 5.630 kasus dengan jumlah kasus baru AIDS sebesar 1.613. ${ }^{3}$ Kota Semarang sebagai ibukota Jawa Tengah dengan mobilitas masyarakatnya yang tinggi juga memiliki kasus HIV/AIDS yang banyak. Sejak tahun 1995-2018, kasus HIV/AIDS di Kota Semarang terus meningkat dengan 5.232 kasus HIV dan 587 kasus AIDS. ${ }^{4}$

HIV/AIDS menimbulkan beberapa masalah pada individu yang terinfeksi. Secara fisik, dampak dari penyakit ini dapat menyebabkan penurunan daya tahan tubuh yang mengakibatkan ODHA rentan dengan penyakit dan infeksi oportunistik lain. Masalah emosional dan sosial yang timbul juga kerap didapatkan ODHA akibat stigma yang ditujukan dari masyarakat. Penyakit ini sering dianggap sebagai penyakit yang bersumber dari perilaku negatif sehingga dampak dari status pasien sebagai ODHA dapat menurunkan kualitas hidupnya. $^{5}$

Kualitas hidup merupakan suatu konsep yang berkaitan dengan pencapaian kehidupan manusia yang ideal atau sesuai dengan yang diinginkan. Dalam bidang kesehatan, konsep ini dikenal sebagai 'Kualitas Hidup terkait Kesehatan' yang dikembangkan untuk menandakan kualitas hidup seseorang yang diukur dari status kesehatan, riwayat penyakit, dan proses penuaan. ${ }^{6}$ CDC telah mendefinisikan kualitas hidup terkait kesehatan sebagai persepsi kesehatan fisik dan mental individu atau kelompok dari waktu ke waktu yang mencakup evaluasi subjektif dari aspek positif dan negatif kehidupan. ${ }^{7}$ Pada konteks ini, pengukuran kualitas hidup meliputi kesehatan fisik, keadaan emosi, kemandirian dalam hidup, tingkat ketergantungan pada lingkungan, hubungannya dengan lingkungan dan keyakinan individu. ${ }^{6}$

Sebagai kelompok masyarakat yang rentan terhadap penyakit oportunistik lain dengan kasus yang terus meningkat setiap tahunnya, ODHA membutuhkan perhatian khusus dalam perawatannya termasuk peningkatan kualitas hidupnya sehingga dapat memperpanjang angka harapan hidup serta mengurangi kasus kematian akibat AIDS di Indonesia karena semakin buruk kualitas hidup yang dimiliki maka semakin besar peluang pasien dengan HIV positif untuk memiliki penyakit AIDS.

Penelitian yang dilakukan oleh Hapsari et.al. terhadap 94 pasien di RSUP Dr. Kariadi Semarang menunjukkan bahwa mayoritas pasien HIV/AIDS masih memiliki kualitas hidup yang kurang baik dalam semua domain, dimana persentase pasien dengan kualitas hidup kurang baik pada domain fisik adalah sebesar $63,0 \%$, pada domain psikologis sebesar $58,0 \%$, pada domain sosial sebesar $54,0 \%$ dan pada domain lingkungan sebesar $33,0 \% .^{8}$ Penelitian yang dilakukan oleh Kusuma terhadap pasien HIV/AIDS di Jakarta menyatakan bahwa pasien dengan jenis kelamin perempuan, dukungan keluarga yang rendah, tingkat pendidikan yang rendah, tidak menikah, tidak bekerja dan memiliki pendapatan yang rendah meningkatkan risiko untuk memiliki kualitas hidup yang buruk. ${ }^{5}$ Wiyati di Yogyakarta juga menyatakan bahwa ODHA yang baru terdiagnosa akan rentan terhadap kondisi stress sehingga menurunkan kualitas hidupnya. ${ }^{9}$ Selain itu, stigma yang 
tinggi ${ }^{10}$, depresi ${ }^{5}$, kepatuhan minum obat yang rendah $^{11}$, usia $<45$ tahun serta lama terapi ART $<3$ bulan $^{12}$ dinyatakan berisiko untuk memiliki kualitas hidup yang buruk.

Dengan mengukur kualitas hidup, suatu penyakit dapat dikaitkan dengan faktor risikonya. Kualitas hidup juga dapat memantau kemajuan tujuan kesehatan suatu negara serta mengidentifikasi suatu kelompok dengan persepsi kesehatan yang buruk sehingga dapat dilakukan intervensi untuk memperbaiki situasi tersebut. $^{7}$

Di antara beberapa penelitian yang telah dilakukan sebelumnya, masih terdapat gap antar tiap penelitian terkait faktor-faktor yang berhubungan dengan kualitas hidup ODHA. Berdasarkan studi pendahuluan yang telah dilakukan peneliti di Yayasan Sehat Peduli Kasih (YS PEKA) juga ditemukan bahwa masih terdapat ODHA yang kemungkinan memiliki kualitas hidup rendah karena belum menikah, pendapatan yang rendah, lama terdiagnosa HIV/AIDS dan lama terapi ART yang kurang dari satu tahun, dukungan keluarga yang rendah, stigma yang diperoleh serta kemungkinan memiliki depresi. Berdasarkan alasan ini maka dilakukan penelitian yang bertujuan untuk mengetahui faktor-faktor yang berhubungan dengan kualitas hidup pada ODHA di Yayasan Sehat Peduli Kasih, Kota Semarang.

\section{Metode}

Penelitian ini merupakan penelitian observasional analitik dengan metode kuantitatif dan desain studi cross-sectional. Penelitian yang dilakukan memiliki tujuan untuk menganalisis hubungan antara jenis kelamin, usia, status pernikahan, status pekerjaan, tingkat pendapatan, lama terdiagnosa, lama terapi ART, tingkat kepatuhan minum obat, tingkat dukungan keluarga, tingkat stigma dan tingkat depresi terhadap kualitas hidup ODHA. Populasi dalam penelitian yaitu ODHA di Kota Semarang yang sedang menjalani terapi ART dan mendapat pendampingan dari Yayasan Sehat Peduli Kasih, Kota Semarang. Besar sampel minimal dihitung menggunakan rumus analitik kategori tidak berpasangan dan didapatkan sampel sebanyak 70 responden yang dipilih menggunakan teknik purposive sampling. Instrumen penelitian menggunakan angket google form yang disebarkan secara daring oleh pengurus yayasan kepada responden melalui media sosial, meliputi pertanyaan seputar karakteristik dan dukungan keluarga serta pernyataan yang mengacu pada kuesioner WHOQOL-HIV BREF untuk mengukur kualitas hidup, Antiretroviral General Adherence Scale (AGAS) untuk mengukur tingkat kepatuhan minum obat, HIV/AIDS Stigma Instrument-PLWHA (HASI-P) untuk mengukur tingkat stigma dan Center Epidemiologic Studies Depression ScaleRevised (CESD-R) untuk mengukur tingkat depresi. Data penelitian dianalisis menggunakan analisis univariat dan bivariat dengan uji chi-square pada tingkat signifikan 5\%. Penelitian ini telah ditinjau dan disetujui oleh Komite Etik Penelitian Kesehatan (KEPK) Fakultas Kesehatan Masyarakat, Universitas Diponegoro dengan nomor ethical clearance 264/EA/KEPK-FKM/2020.

\section{Hasil}

Dari penelitian yang telah dilakukan pada bulan Oktober-November 2020 di Yayasan Sehat Peduli Kasih Kota Semarang terhadap 70 responden, diperoleh hasil dengan analisis univariat dan bivariat sebagai berikut:

Tabel 1. Distribusi Frekuensi Variabel Penelitian

\begin{tabular}{lrr}
\hline \multicolumn{1}{c}{ Variabel } & N & \% \\
\hline Jenis Kelamin & & \\
Laki-laki \\
$\begin{array}{l}\text { Perempuan } \\
\text { Usia }\end{array}$ & 57 & 81,4 \\
$<32$ tahun & 13 & 18,6 \\
$\begin{array}{l}\text { 32 tahun } \\
\text { Status Pernikahan }\end{array}$ & 37 & 52,9 \\
Belum menikah tidak ada & 36 & 51,4 \\
pasangan & & \\
Belum menikah ada pasangan & & \\
Sudah menikah & 8 & 11,4 \\
Cerai hidup & 20 & 28,6 \\
Cerai mati & 4 & 5,7 \\
& 2 & 2,9
\end{tabular}


Tingkat Pendidikan

$<$ Tamat SMA

$\geq$ Tamat SMA

Pendidikan Saat Ini

Perguruan tinggi

SMA/sederajat

Tidak ada

Status Pekerjaan

Belum bekerja

Sudah bekerja

Jenis Pekerjaan

Tidak ada

Karyawan swasta

Pengurus yayasan

Wirausaha

Buruh bangunan

Akademisi

Ibu rumah tangga

Pegawai negeri

Pengamen

Satpam

Tingkat Pendapatan

$<$ Rp 1.250 .000

$\geq \mathrm{Rp} 1.250 .000$

Lama Terdiagnosa

$<3$ tahun 5 bulan

$\geq 3$ tahun 5 bulan

Stadium Klinis Awal

Stadium I

Stadium II

Stadium III

Stadium IV

Lama Terapi ART

$<3$ tahun

$\geq 3$ tahun

Tingkat Kepatuhan Minum

Obat

Rendah

Tinggi

Pengingat Jadwal Minum Obat

Anak

Keluarga

Orangtua

Pasangan

Teman

Tidak ada

Keterbukaan Status HIV pada

\section{Keluarga}

Anak

Keluarga inti

Orangtua

Pasangan

Saudara kandung

Tidak terbuka
32,9

Tingkat Dukungan Keluarga

\begin{tabular}{lcc} 
Rendah & 32 & 45,7 \\
Tinggi & 38 & 54,3 \\
Tingkat Stigma & & \\
$\begin{array}{l}\text { Rendah } \\
\text { Tinggi }\end{array}$ & 34 & 48,6 \\
Tingkat Depresi & 36 & 51,4 \\
Ada gejala & & \\
Tanpa gejala & 41 & 58,6 \\
Tingkat Kualitas Hidup & 29 & 41,4 \\
Buruk & & \\
Baik & 38 & 54,3 \\
& 32 & 45,7 \\
\hline
\end{tabular}

Berdasarkan tabel 1 diketahui bahwa mayoritas reponden dalam penelitian ini memiliki kualitas hidup yang buruk, dimana terdapat beberapa faktor risiko yang mungkin meningkatkan peluang tersebut dimana mayoritas reponden berjenis kelamin laki-laki, rata-rata berusia 32 tahun, belum menikah dan tidak memiliki pasangan, dengan tingkat pendidikan SMA atau perguruan tinggi, sudah bekerja, memiliki pendapatan yang jauh di bawah UMK Kota Semarang, rata-rata telah terdiagnosa selama 3 tahun 5 bulan dengan lama terapi 3 tahun, memiliki kepatuhan minum obat, dukungan keluarga dan stigma yang tinggi dan menunjukkan gejala depresi. $\begin{array}{ll}30 & 42,9 \\ 40 & 57,1\end{array}$

$34 \quad 48,6$

$36 \quad 51,4$

$4 \quad 5,7$

$6 \quad 8,6$

$6 \quad 8,6$

$16 \quad 22,9$

$11 \quad 15,7$

$27 \quad 38,6$

34,3

$26 \quad 37,1$

$10 \quad 14,3$

$8 \quad 11,4$

$5 \quad 7,1$

$18 \quad 25,7$ 
Tabel 2. Analisis Hubungan Variabel Penelitian dengan Tingkat Kualitas Hidup

\begin{tabular}{|c|c|c|c|c|c|}
\hline \multirow[b]{2}{*}{ Variabel } & \multicolumn{2}{|c|}{ Kualitas Hidup } & \multirow[b]{2}{*}{$p$} & \multirow[b]{2}{*}{ POR } & \multirow[b]{2}{*}{$95 \% \mathrm{CI}$} \\
\hline & $\begin{array}{l}\text { Buruk } \\
\mathrm{n}(\%)\end{array}$ & $\begin{array}{l}\text { Baik } \\
\mathrm{n}(\%)\end{array}$ & & & \\
\hline \multicolumn{6}{|l|}{ Jenis Kelamin } \\
\hline Perempuan & $8(61,5)$ & $5(38,5)$ & 0,561 & & \\
\hline Laki-laki & $30(52,6)$ & $27(47,4)$ & & & \\
\hline \multicolumn{6}{|l|}{ Usia } \\
\hline$<32$ tahun & $23(62,2)$ & $14(37,8)$ & 0,161 & & \\
\hline$\geq 32$ tahun & $15(45,5)$ & $18(54,5)$ & & & \\
\hline \multicolumn{6}{|l|}{ Status Pernikahan } \\
\hline Cerai mati & $2(100,0)$ & $0(0,0)$ & 0,134 & & \\
\hline Belum menikah ada pasangan & $5(62,5)$ & $3(37,5)$ & & & \\
\hline $\begin{array}{l}\text { Belum menikah tidak ada } \\
\text { pasangan }\end{array}$ & $21(58,3)$ & $15(41,7)$ & & & \\
\hline Sudah menikah & $10(50,0)$ & $10(50,0)$ & & & \\
\hline Cerai hidup & $0(0,0)$ & $4(100,0)$ & & & \\
\hline \multicolumn{6}{|l|}{ Tingkat Pendidikan } \\
\hline$<$ SMA/sederajat & $15(65,2)$ & $8(34,8)$ & 0,199 & & \\
\hline$\geq \mathrm{SMA} /$ sederajat & $23(48,9)$ & $24(51,1)$ & & & \\
\hline \multicolumn{6}{|l|}{ Status Pekerjaan } \\
\hline Belum bekerja & $18(66,7)$ & $9(33,3)$ & 0,099 & & \\
\hline Sudah bekerja & $20(46,5)$ & $23(53,5)$ & & & \\
\hline \multicolumn{6}{|l|}{ Tingkat Pendapatan } \\
\hline$<\operatorname{Rp} 1.250 .000$ & $25(69,4)$ & $11(30,6)$ & 0,009 & 1,82 & $1,12-2,93$ \\
\hline$\geq \operatorname{Rp} 1.250 .000$ & $13(38,2)$ & $21(61,8)$ & & & \\
\hline \multicolumn{6}{|l|}{ Lama Terdiagnosa } \\
\hline$<3$ tahun 5 bulan & $25(71,4)$ & $10(28,6)$ & 0,004 & 1,92 & $1,19-3,10$ \\
\hline$\geq 3$ tahun 5 bulan & $13(37,1)$ & $22(62,9)$ & & & \\
\hline \multicolumn{6}{|l|}{ Lama Terapi ART } \\
\hline$<3$ tahun & $25(73,5)$ & $9(26,5)$ & 0,002 & 2,04 & $1,26-3,29$ \\
\hline$\geq 3$ tahun & $13(36,1)$ & $23(63,9)$ & & & \\
\hline $\begin{array}{l}\text { Tingkat Kepatuhan Minum } \\
\text { Obat }\end{array}$ & & & & & \\
\hline Rendah & $17(56,7)$ & $13(43,3)$ & 0,729 & & \\
\hline Tinggi & $21(52,5)$ & $19(47,5)$ & & & \\
\hline \multicolumn{6}{|l|}{ Tingkat Dukungan Keluarga } \\
\hline \multicolumn{6}{|l|}{ Rendah } \\
\hline \multirow{2}{*}{ Tinggi } & $23(71,9)$ & $9(28,1)$ & 0,007 & 1,82 & $1,16-2,85$ \\
\hline & $15(39,5)$ & $23(60,5)$ & & & \\
\hline \multicolumn{6}{|l|}{ Tingkat Stigma } \\
\hline Tinggi & $27(75,0)$ & $9(25,0)$ & $<0,001$ & 0,43 & $0,26-0,72$ \\
\hline Rendah & $11(32,4)$ & $23(67,6)$ & & & \\
\hline \multicolumn{6}{|l|}{ Tingkat Depresi } \\
\hline Ada gejala & $33(80,5)$ & $8(19,5)$ & $<0,001$ & 4,67 & $2,08-$ \\
\hline Tanpa gejala & $5(17,2)$ & $24(82,8)$ & & & 10,51 \\
\hline
\end{tabular}


Berdasarkan tabel 2 dapat diketahui bahwa responden dengan tingkat pendapatan di bawah Rp 1.250.000 berisiko sebesar 1,82 kali untuk memiliki kualitas hidup yang buruk. Responden yang telah terdiagnosa selama kurang dari 3 tahun 5 bulan dan telah menjalani terapi selama kurang dari 3 tahun masingmasing dikatakan memiliki risiko sebesar 1,92 dan 2,04 kali untuk memiliki kualitas hidup yang buruk. Responden dengan tingkat dukungan keluarga yang rendah, tingkat stigma yang tinggi serta menunjukkan gejala depresi juga berisiko untuk memiliki kualitas hidup yang buruk masing-masing sebesar 1,82 kali, 0,43 kali dan 4,67 kali.

\section{Pembahasan}

\section{Jenis Kelamin}

Mayoritas responden dalam penelitian ini adalah laki-laki, dimana umumnya mereka lebih rentan terinfeksi HIV karena berdasarkan cara penularan laki-laki lebih banyak terpapar dengan kejadian infeksi HIV melalui IDU, homoseksual dan heteroseksual, sedangkan wanita umumnya terpapar melalui satu penularan yaitu hubungan heteroseksual. Pada tingkat kualitas hidup, responden perempuan memiliki kualitas hidup yang lebih buruk karena dalam menghadapi stressor, perempuan lebih menggunakan perasaan dibanding lakilaki yang menggunakan logika sehingga menjalani pengobatan dalam waktu yang lama, adanya komplikasi dan tekanan sosial dapat berdampak signifikan pada status psikologisnya dan menurunkan kualitas hidup. ${ }^{5}$ Namun berdasarkan uji chi-square, ditemukan bahwa tidak ada hubungan antara jenis kelamin dengan kualitas hidup ODHA ( $p$-value = 0,561).

Hasil penelitian ini sejalan dengan penelitian yang dilakukan Rokhani di Semarang dan Zainudin di Kupang yang menyatakan bahwa jenis kelamin bukanlah suatu faktor yang mempengaruhi kualitas hidup ODHA. ${ }^{13,14}$ Hal ini dapat disebabkan karena perbedaan kualitas hidup antara laki-laki dan perempuan bergantung pada banyak faktor, misalnya perbedaan fisiologis, genetik, tekanan emosional, kebiasaan individu dan pelayanan medis. ${ }^{12}$ Kualitas hidup yang baik maupun yang buruk juga dapat terjadi pada siapapun tanpa memandang jenis kelaminnya. Artinya, setiap orang memiliki kesempatan yang sama untuk meningkatkan kualitas hidupnya. ${ }^{13}$ Menurut peneliti, dukungan dari sesama anggota dan klien di YS PEKA tanpa membeda-bedakan jenis kelamin juga dapat membantu ODHA mengurangi tekanan psikologis dan rasa kesendirian. Adanya pertemuan anggota dan klien yang diadakan rutin setiap bulannya mewujudkan wadah bagi mereka untuk saling bercerita dan berkeluh kesah, sehingga pertemuan tersebut menjadi sebuah system support tambahan bagi responden. Pertemuan yang diadakan juga tidak membatasi partisipan berdasarkan jenis kelaminnya, sehingga setiap pasien memiliki kesempatan yang sama untuk mengikuti pertemuan tersebut.

\section{Usia}

Rata-rata usia responden dalam penelitian ini adalah 32 tahun, dimana hasil ini menunjukkan sedikit kemiripan dengan penelitian yang dilakukan oleh Carsita di Bongas dimana rata-rata responden tergolong dalam usia produktif yaitu 33 tahun. Usia yang produktif memungkinkan ODHA masih memiliki fisik yang kuat, mampu bekerja dengan baik, berkarya serta beraktivitas secara mandiri. ${ }^{15}$

Usia berkaitan dengan pola pikir dan kematangan seseorang untuk menilai jenis stressor yang dihadapi, kemampuan beradaptasi serta pembentukan mekanisme koping yang adaptif sehingga dapat disimpulkan bahwa usia berhubungan dengan perilaku seseorang dalam mengambil keputusan. ${ }^{9}$ Namun berdasarkan uji chi-square ditemukan bahwa tidak ada hubungan antara usia dengan kualitas hidup ODHA ( $p$-value = 0,161). Hal ini sejalan dengan penelitian yang dilakukan oleh Wiyati dan Saputra di Yogyakarta yang menyatakan bahwa usia bukanlah faktor yang mempengaruhi kualitas hidup. ${ }^{9,16}$

Secara umum, usia berhubungan dengan kematangan psikologis seseorang namun belum pasti berhubungan dengan kualitas hidupnya. Bagi ODHA, kualitas hidup tidak dipengaruhi oleh usia karena diagnosa HIV/AIDS sendiri sudah cukup menjadi stressor yang mempengaruhi aspek-aspek dalam 
kehidupannya, sehingga kualitas hidupnya tidak hanya terbatas pada usia yang lebih tua maupun muda. ${ }^{9}$ Setiap individu akan mengalami proses kematangan yang berbeda yang didapat dari lingkungan, sosial, kemampuan dalam menilai jenis stressor, kemampuan beradaptasi dan mekanisme koping yang adaptif. $^{16}$ Menurut peneliti, kualitas hidup merupakan suatu konsep yang subjektif sehingga tingkat kualitas hidup seseorang tidak terbatas pada usianya, baik usia muda maupun tua dapat mempunyai kualitas hidup yang baik bergantung pada bagaimana mereka mempersepsikan kondisi kesehatannya masing-masing.

\section{Status Pernikahan}

Mayoritas responden dalam penelitian ini belum menikah dan tidak memiliki pasangan, sedangkan responden yang memiliki status pernikahan cerai mati memiliki kualitas hidup yang paling buruk. Pasien dengan status menikah akan mempunyai sumber koping yang cukup dari pasangannya sehingga mereka dapat lebih mengembangkan sikap koping yang adaptif terhadap stressor yang dihadapi. Dengan adanya pasangan yang mendampingi dan memberi dukungan, maka pasien dapat merasa lebih optimis dalam menjalani kehidupannya sehingga keseluruhan aspek dalam kualitas hidupnya juga ikut meningkat. ${ }^{5}$ Namun berdasarkan uji chi-square ditemukan bahwa tidak ada hubungan antara status pernikahan dengan kualitas hidup ODHA ( $p$ value $=0,134$ ).

Hasil penelitian ini sejalan dengan penelitian yang dilakukan oleh Zainudin di Kupang dimana status pernikahan bukanlah faktor yang berhubungan dengan kualitas hidup seseorang. ${ }^{14}$ Menurut peneliti, walaupun mayoritas responden dalam penelitian ini berstatus belum menikah dan tidak mempunyai pasangan serta responden yang berstatus cerai mati memiliki kualitas hidup yang paling buruk, mereka tetap mendapat dukungan dari keluarga, teman-teman serta pengurus yayasan sehingga dukungan utama tidak semata-mata berasal dari pasangan saja.

\section{Tingkat Pendidikan}

Mayoritas responden dalam penelitian ini memiliki tingkat pendidikan SMA dan perguruan tinggi, sedangkan responden dengan pendidikan yang lebih rendah memiliki kualitas hidup yang lebih buruk. Responden dengan tingkat pendidikan lebih tinggi cenderung memiliki sikap yang lebih waspada terhadap penyakit seiring dengan kesadaran publik yang meningkat terkait HIV/AIDS. Individu dengan pendidikan tinggi cenderung memiliki kemampuan kognitif yang lebih baik untuk menerima dan mencari informasi terkait penyakit dan perawatannya. Tingkat pendidikan juga berhubungan dengan keterampilan manajemen diri untuk menghadapi penyakit dan berbagai permasalahan lain, memudahkan akses terhadap informasi, meningkatkan kemampuan pasien untuk melakukan pemecahan masalah serta pengambilan keputusan secara aktif terkait penyakitnya. ${ }^{9}$ Responden yang berpendidikan tinggi mungkin memiliki penghasilan yang lebih baik sehingga hidup dalam kondisi finansial yang lebih stabil. ${ }^{17}$ Penghasilan yang lebih tinggi dapat membuat ODHA merasa tercukupi dalam menjalani kehidupan sehari-hari sehingga meningkatkan kualitas hidupnya. Namun berdasarkan uji chisquare ditemukan bahwa tidak ada hubungan antara tingkat pendidikan dengan kualitas hidup ODHA ( $p$-value $=0,199)$.

Hasil penelitian sejalan dengan penelitian yang dilakukan oleh Wiyati di Yogyakarta dimana tingkat pendidikan tidak berhubungan dengan kualitas hidup ODHA. ${ }^{9}$ Menurut peneliti, hal ini dapat disebabkan karena pengurus yayasan yang rutin mengadakan pertemuan dengan sesama pengurus maupun kliennya sehingga walaupun tidak seluruh responden memiliki pendidikan yang tinggi, pengetahuan serta kesadaran mereka terkait kondisinya tetap meningkat karena informasi yang disampaikan oleh pengurus yayasan disampaikan secara rutin dalam bahasa yang mudah dipahami. Berdasarkan penelitian sebelumnya, ditemukan juga bahwa semakin tinggi pengetahuan maka semakin tinggi peluang perubahan perilaku terjadi. ${ }^{17}$ Dengan pengetahuan yang meningkat, walaupun 
berpendidikan rendah mereka tetap memiliki peluang untuk melakukan modifikasi perilaku khususnya yang bertujuan untuk meningkatkan kualitas hidupnya

\section{Status Pekerjaan}

Mayoritas responden dalam penelitian ini sudah memiliki pekerjaan dengan responden yang belum bekerja memiliki kualitas hidup yang lebih buruk. Pekerjaan merupakan keprihatinan utama tersendiri bagi ODHA karena mereka yang sudah bekerja cenderung memiliki kondisi finansial yang lebih baik sehingga dapat berperan positif dalam meningkatkan kualitas hidupnya. ${ }^{16}$ Pekerjaan berkaitan dengan status ekonomi dimana semakin tinggi status ekonomi maka kemampuan individu untuk membiayai kebutuhannya juga meningkat. Adanya pekerjaan merupakan sumber utama seseorang memiliki penghasilan, sehingga dengan tidak adanya pekerjaan maka menjadi suatu stressor tersendiri bagi ODHA dalam menjalani hidupnya. Hal ini juga mungkin berkaitan dengan ketergantungan individu terhadap orang lain, tingkat kemandirian, serta aspek lainnya dalam kualitas hidup. Namun berdasarkan uji chi-square ditemukan bahwa tidak ada hubungan antara status pekerjaan dengan kualitas hidup ODHA ( $p$-value $=0,099$ ).

Hasil penelitian sejalan dengan penelitian yang dilakukan oleh Wiyati di Yogyakarta dimana status pekerjaan tidak berhubungan dengan kualitas hidup ODHA. Hal ini dapat disebabkan karena ODHA yang belum bekerja mungkin memiliki kesadaran dalam meningkatkan kualitas hidupnya serta menjaga kondisi kesehatannya. ${ }^{9}$ Menurut peneliti, secara umum ODHA mempunyai keinginan dan motivasi untuk hidup sehat dan sudah memiliki pengetahuan serta kesadaran untuk menjaga kualitas hidupnya walaupun beberapa responden sedang tidak bekerja.

\section{Tingkat Pendapatan}

Mayoritas responden dalam penelitian ini memiliki pendapatan di bawah $\mathrm{Rp} 1.250 .000$ dan dinyatakan memiliki kualitas hidup yang lebih buruk. Pada analisis bivariat, ditemukan bahwa terdapat hubungan antara tingkat pendapatan dengan kualitas hidup ODHA dimana hal tersebut sejalan dengan penelitian yang dilakukan oleh Kusuma di Jakarta dimana responden dengan pendapatan yang lebih rendah lebih berisiko untuk memiliki kualitas hidup yang buruk. Tidak adanya sumber pendapatan memiliki efek negatif tersendiri pada kualitas hidup seseorang. Pasien yang mempunyai pendapatan yang mencukupi dapat menunjang pemenuhan kebutuhan hidupnya sehingga menjaga kondisi eksehatan responden dalam berbagai aspek. ${ }^{5}$ Hasil penelitian juga sejalan dengan penelitian yang dilakukan Mardia di Surakarta dimana status ekonomi dan kecukupan finansial memiliki hubungan terhadap kepuasan kualitas hidup seseorang. Pasien yang dapat menjangkau fasilitas kesehatan dengan kendaraan pribadi memiliki kualitas hidup yang lebih baik dibandingkan pasien yang berjalan kaki atau menggunakan angkutan umum. Hal ini dapat disebabkan karena pasien merasa lelah atau tidak nyaman untuk berjalan kaki di bawah cuaca yang terik, atau keadaan jalanan yang padat dan transportasi umum yang sesak dan kurang nyaman ketika menjangkau fasilitas kesehatan. Dampaknya, jarak dan waktu yang lama juga berpeluang dalam menimbulkan kejadian loss to follow up ketika menjalani pengobatan. ${ }^{12}$

Menurut peneliti, semakin tinggi pendapatan maka semakin tinggi pula kualitas hidupnya karena berdasarkan hasil penelitian, $54,3 \%$ responden memiliki kualitas hidup yang buruk dan $51,4 \%$ responden memiliki pendapatan di bawah Rp 1.250.000. Artinya, mayoritas responden memiliki pendapatan yang tergolong rendah dengan kualitas hidup yang buruk. Sebanyak 20,0\% responden juga menyatakan bahwa mereka tidak memiliki cukup uang dalam menjalani kehidupan dan $38,6 \%$ responden menyatakan bahwa mereka tidak mempunyai pekerjaan sebagai sumber utama penghasilan. Pendapatan yang lebih tinggi dapat membuat responden merasa tercukupi dalam memenuhi biaya kebutuhannya sehari-hari.

\section{Lama Terdiagnosa}

Rata-rata lama terdiagnosa responden dalam penelitian ini adalah 3 tahun 5 bulan, dimana responden yang telah terdiagnosa selama kurang dari 3 tahun 5 bulan memiliki 
kualitas hidup yang lebih buruk. Penurunan daya tahan tubuh yang progresif menyebabkan ODHA rentan terhadap infeksi dan keganasan. ${ }^{5}$ Kualitas hidup dapat menentukan lama hidup pasien HIV/AIDS, dimana pasien yang memiliki kualitas hidup yang lebih baik cenderung memiliki kemampuan bertahan hidup yang lebih lama. Hal ini mungkin disebabkan oleh konsistensi pasien dalam mengonsumsi obat ARV sehingga jumlah virus dapat ditekan dan organ tubuh tetap berfungsi secara maksimal. ${ }^{13}$

Menurut peneliti, pada awal terdiagnosa ODHA rentan mengalami stress karena hal tersebut berkaitan dengan koping yang digunakan ODHA untuk beradaptasi dengan stressor. Individu yang menghadapi stress dengan modifikasi perilaku memiliki kualitas hidup yang jauh lebih baik daripada mereka yang belum mampu mengembangkan kemampuan tersebut. Dengan lama terdiagnosa selama 3 tahun 5 bulan memungkinkan ODHA untuk merasa terbiasa dengan kondisinya sehingga mampu beradaptasi dengan penyakit yang diderita. Hasil penelitian serupa dengan karakteristik responden yang hampir mirip ditemukan pada penelitian yang dilakukan oleh Mardia di Surakarta dimana pasien dengan lama terdiagnosa lebih dari atau sama dengan 2 tahun 8 bulan memiliki peluang sebesar dua kali untuk memiliki kualitas hidup yang lebih baik. Dengan seiring berjalannya waktu, pasien tidak hanya melihat tingkat kerentanan terhadap infeksi oportunistik namun juga pengalaman yang telah menjadikan mereka terbiasa menjalani kondisinya. ${ }^{12}$

\section{Lama Terapi ART}

Mayoritas responden dalam penelitian ini telah menjalani terapi ART selama lebih dari atau sama dengan 3 tahun, dimana responden dengan lama terapi kurang dari 3 tahun memiliki kualitas hidup yang lebih buruk. Hasil penelitian menunjukkan bahwa terdapat hubungan antara lama terapi ART dengan kualitas hidup ODHA. Telah diketahui bahwa obat ARV bertujuan untuk meningkatkan umur harapan hidup dan terbukti efektif memperpanjang hidup ODHA. Menurut penuturan ketua YS PEKA, ODHA yang rutin mengonsumsi obat ARV umumnya memiliki kondisi kesehatan yang lebih baik, walaupun mereka sudah berada pada stadium 4 (AIDS). Salah satu responden juga menuturkan bahwa karena ia rajin mengonsumsi obat ARV, jumlah virus HIV dalam tubuh menurun atau mencapai tahap tidak terdeteksi. Pengkonsumsian obat ARV pada ODHA merupakan upaya untuk memperpanjang umur harapan hidup. Obat ARV bekerja melawan infeksi dengan memperlambat reproduksi HIV di dalam tubuh sehingga obat ini bukan untuk menyembuhkan namun untuk memperpanjang hidup ODHA sehingga membantu mereka menjadi lebih sehat dan lebih produktif dengan mengurangi jumlah viremia dan meningkatkan jumlah sel CD4. ${ }^{17}$ Secara fisik, pasien yang telah menjalani terapi rutin dapat beraktivitas secara normal.

\section{Tingkat Kepatuhan Minum Obat}

Mayoritas responden dalam penelitian ini menunjukkan tingkat kepatuhan yang tinggi, dimana responden dengan tingkat kepatuhan yang rendah memiliki kualitas hidup yang lebih buruk. Obat ARV dapat memperpanjang umur harapan hidup ODHA, menjaga kesehatan fisik serta meningkatkan manajemen penyakit. Untuk menekan jumlah virus yang baik maka diperlukan tingkat kepatuhan ARV yang tinggi. Tingkat kepatuhan yang lebih rendah mungkin saja terjadi karena faktor biaya untuk berobat misalnya biaya transportasi ke fasilitas kesehatan, adanya efek samping obat serta stigma terhadap pasien HIV/AIDS. ${ }^{17}$ Namun berdasarkan uji chi-square ditemukan bahwa tidak ada hubungan antara tingkat kepatuhan minum obat dengan kualitas hidup ODHA ( $p$ value $=0,729$ ).

Obat ARV mampu mempengaruhi imunitas, mengendalikan viral load dan menunda progresi penyakit. Ketidakpatuhan terhadap terapi akan memberi waktu kepada virus untuk bereplikasi sehingga menyebabkan penurunan $\mathrm{CD} 4$ dan menimbulkan resistensi dalam tubuh ODHA terhadap obat ARV yang diberikan. ${ }^{11}$ Namun, menurut asumsi peneliti, kepatuhan minum obat ARV tidak menjadi faktor langsung atau faktor utama yang berhubungan dengan kualitas hidup ODHA karena terdapat banyak elemen atau faktor lain 
yang berhubungan dengan tingkat kepatuhan minum obat itu sendiri, seperti status pekerjaan, jenis kombinasi ARV, efek samping obat serta dukungan keluarga. Kepatuhan ART juga berhubungan dengan kompleksitas regimen obat dan toksisitas obat. ${ }^{18}$

\section{Tingkat Dukungan Keluarga}

Mayoritas responden dalam penelitian ini memiliki tingkat dukungan keluarga yang tinggi, dimana responden dengan dukungan keluarga yang rendah menunjukkan skor kualitas hidup yang lebih buruk. Berdasarkan analisis bivariat juga ditemukan bahwa terdapat hubungan antara tingkat dukungan keluarga dengan kualitas hidup ODHA.

Keluarga merupakan seseorang yang berhubungan paling dekat dengan pasien sehingga dukungan keluarga sangat dibutuhkan sebagai support system yang dapat mendukungnya mengembangkan respon yang efektif dalam menghadapi stressor baik secara fisik, psikis maupun sosial. Dengan adanya dukungan keluarga yang cukup maka akan memberi dampak positif terhadap peningkatan kualitas hidup pasien HIV/AIDS. Hasil penelitian ini sejalan dengan penelitian yang dilakukan Kusuma di Jakarta dimana ODHA dengan dukungan keluarga yang non-suportif berisiko lebih besar untuk memiliki kualitas hidup yang kurang baik setelah dikontrol oleh jenis kelamin, status marital dan stadium penyakit. Hasil ini juga sejalan dengan penelitian Wig yang menunjukkan adanya hubungan yang signifikan antara dukungan keluarga dengan kualitas hidup ODHA setelah dikontrol oleh tingkat pendidikan, penghasilan, pekerjaan dan kategori klinis penyakit. ${ }^{5}$

ODHA dengan dukungan keluarga yang tinggi cenderung memiliki kualitas hidup yang lebih baik karena mereka merasa bahwa dirinya lebih didukung dan menganggap keluarga sebagai sumber utama dukungan. Tidak adanya tekanan akan membuat ODHA merasa aman dan cenderung patuh menjalankan pengobatan. ${ }^{15}$ Dengan adanya dukungan keluarga yang komprehensif diharapkan ODHA dapat termotivasi dan lebih bersabar menerima kondisinya. Peran keluarga dapat membantu ODHA maupun anggota keluarga lainnya untuk menerima kondisi yang dihadapi. ${ }^{16}$ Keluarga yang hidup dengan HIV akan menghadapi banyak tantangan sehingga dengan dukungan yang mencukupi, tantangan tersebut dapat diatasi bersama. ${ }^{12}$

\section{Tingkat Stigma}

Mayoritas responden dalam penelitian ini masih memperoleh stigma yang tinggi dengan kualitas hidup yang lebih buruk. Berdasarkan analisis bivariat, ditemukan hubungan antara tingkat stigma dengan kualitas hidup ODHA. Stigma adalah sikap negatif yang timbul akibat keyakinan atau pengetahuan seseorang. ${ }^{17}$ Masalah sosial yang dihadapi ODHA cukup memprihatinkan karena adanya stigma. Stigma juga muncul karena pemahaman masyarakat yang kurang mengenai HIV/AIDS sehingga dianggap sebagai penyakit mematikan yang mudah menular melalui kontak fisik biasa. Hal ini menyebabkan pasien sering dikucilkan dan mendapat perilaku diskriminatif dari orang di sekitarnya. $^{5}$

Stigma muncul karena ketidaktahuan masyarakat mengenai informasi HIV yang benar dan lengkap, khususnya terkait mekanisme penularan. Stigma merupakan penghalang terbesar dalam pencegahan penularan dan pengobatan HIV karena stigma menyebabkan orang yang memiliki gejala HIV/AIDS enggan melakukan tes untuk mengetahui status HIV-nya karena takut akan mendapat stigma dari orang di sekitarnya. Stigma juga menghalangi ODHA melakukan aktivitas sosial sehingga mereka menutup diri dan cenderung tidak bersedia melakukan interaksi dengan keluarga, teman dan tetangga. Adanya stigma dapat berdampak serius bagi ODHA karena dapat membuat mereka enggan mencari pelayanan kesehatan dan dukungan sosial yang semestinya mereka peroleh. Adanya stigma juga dapat membuat ODHA harus kehilangan pekerjaan, asuransi, layanan umum bahkan ditolak untuk mendapat pendidikan di sekolah. Stigma bukan hanya dapat mempengaruhi hidup ODHA namun juga orang-orang di sekitarnya. ${ }^{10}$ Stigma juga dapat menjadi salah satu faktor mengapa masih ada beberapa ODHA dalam penelitian ini yang belum terbuka akan status HIV-nya.

Hasil penelitian ini sejalan dengan penelitian yang dilakukan oleh Mariany di 
Pematangsiantar yang menyatakan bahwa tingkat stigma mempengaruhi kualitas hidup ODHA, dimana semakin tinggi stigma yang diperoleh responden maka semakin buruk kualitas hidupnya. ${ }^{10}$ Hasil penelitian serupa juga ditemukan pada penelitian yang dilakukan oleh Handayani di Kupang yang menunjukkan terdapat hubungan yang signifikan antara stigma dengan kualitas hidup ODHA. $^{17}$ Ketidakterbukaan pasien mengenai status HIVnya dapat berdampak pada perilaku pencegahan HIV, perilaku mencari perawatan, serta kualitas untuk perawatan dan pengobatan pada ODHA sehingga diperlukan program pencegahan dan pengobatan HIV untuk mengurangi stigma.

\section{Tingkat Depresi}

Mayoritas responden dalam penelitian ini menunjukkan gejala depresi dengan kualitas hidup yang lebih buruk. Berdasarkan analisis bivariat juga ditemukan hubungan antara tingkat depresi dengan kualitas hidup ODHA.

Depresi adalah penyakit suasana hati, merupakan kesedihan atau dukacita yang hebat dan biasanya bertahan lama. Depresi dapat menyebabkan beberapa dampak negatif, salah satunya penurunan sistem kekebalan yang menyebabkan individu merasa lelah dan lesu bahkan saat melakukan aktivitas tubuh yang ringan dapat menyebabkan kelelahan ekstrim yang juga umum terjadi pada ODHA. ${ }^{19}$

Kondisi fisik yang tidak stabil dan adanya tekanan sosial mengakibatkan ODHA rentan mengalami gangguan psikososial seperti depresi yang dapat menurunkan kondisi kesehatannya karena modulasi sistem imun dalam keadaan stress berkepanjangan dapat menurunkan jumlah sel CD4. Pasien yang mengalami depresi cenderung tidak aktif mencari informasi maupun berpartisipasi dalam manajemen pengobatan yang dijalani untuk menjaga kondisi kesehatannya. Keadaan depresi juga akan membuat pasien merasa pesimis, memandang dirinya tidak berharga sampai mengisolasi diri dari lingkungan sosial yang berdampak pada kualitas hidupnya. Pasien HIV/AIDS di negara berkembang juga ditemukan lebih berisiko terkena depresi karena terbentur keadaan ekonomi yang sulit sehingga menjadi stressor tambahan bagi pasien. Secara konsep, pasien HIV/AIDS menghadapi banyak stressor seperti kondisi fisik yang semakin menurun seiring perjalanan penyakit, tekanan sosial yang dihadapi, ketakutan akan kematian sampai masalah keluarga maupun ekonomi. Dengan stressor yang kompleks tersebut, seringkali pasien gagal mengembangkan koping adaptif sehingga mengalami depresi. ${ }^{5}$

Depresi merupakan kejadian yang lebih sering terjadi pada pasien HIV dibanding individu non-pasien HIV. Depresi pada ODHA dapat menyebabkan hasil yang lebih buruk pada perilaku dan kondisi klinis, termasuk kualitas hidupnya. Menurut studi yang dilakukan oleh Jiang di Cina, individu yang mengalami kejadian negatif seperti infeksi HIV, memiliki masalah finansial, terdiagnosa AIDS, diskriminasi dan sebagainya memiliki prevalensi yang lebih tinggi untuk mengalami depresi berat setelah dikontrol oleh umur dan jenis kelamin. ${ }^{20}$

Hasil penelitian sejalan dengan penelitian yang dilakukan Kusuma di Jakarta dimana ODHA yang mengalami depresi berisiko lebih besar untuk memiliki kualitas hidup yang buruk setelah dikontrol oleh jenis kelamin, status pernikahan dan stadium penyakit. Penelitian serupa oleh Abiodun juga menunjukan adanya hubungan yang signifikan antara depresi dengan kualitas hidup ODHA setelah dikontrol oleh tingkat pendidikan, tingkat sosial ekonomi dan dukungan sosial. ${ }^{5}$

ODHA yang depresi membutuhkan dukungan baik emosional, informasi dan material sehingga ODHA merasa nyaman, aman dan dapat belajar lebih banyak. Dukungan yang tidak cukup dapat membuat ODHA semakin terpuruk dan perlahan menurunkan kualitas hidupnya. Kondisi depresi dapat memberi dampak buruk bagi kualitas hidup yang sangat penting untuk diperhatikan karena HIV/AIDS bersifat kronis dan progresif sehingga berdampak luas pada aspek kehidupan. Masalah psikososial seperti depresi terkadang lebih berat untuk dihadapi pasien karena bergantung pula dengan pengobatan kondisi tersebut sehingga menimbulkan multi stressor bagi pasien dan semakin menurunkan kualitas hidupnya. ${ }^{10}$ 


\section{Keterbatasan Penelitian}

Dalam menyebarkan angket penelitian, peneliti tidak dapat terjun langsung dan mengawasi responden secara langsung karena kondisi pelaksanaan penelitian dilakukan di tengah pandemi COVID-19 sehingga tidak memungkinkan untuk melakukan observasi dan wawancara langsung dengan responden sehingga peneliti menyebarkan angket secara daring dalam bentuk google form. Respon bias dari responden mungkin muncul karena informasi yang diberikan responden melalui angket daring terkadang tidak menunjukkan pendapat responden yang sebenarnya. Hal ini bisa terjadi karena adanya ketidakmampuan responden dalam memahami isi pertanyaan sehingga berpengaruh terhadap jawaban yang diberikan. Karenanya, peneliti melakukan antisipasi dengan memodifikasi angket dengan bahasa yang mudah dipahami oleh masyarakat umum, memberikan deskripsi kondisi dalam pernyataan yang diajukan serta mengestimasi frekuensi skala pilihan jawaban sehingga responden diharapkan lebih mudah memahami dan menjawab pertanyaan yang ada. Selain itu, peneliti juga menemukan kesulitan untuk meningkatkan partisipasi responden walau telah diberikan mengajukan reward penelitian berupa saldo uang elektronik. Karena penelitian dilakukan secara daring maka peneliti tidak dapat melakukan persuasi secara langsung kepada responden yang sesuai dengan kriteria penelitian.

\section{Kesimpulan}

Jenis kelamin, usia, status pernikahan, tingkat pendidikan, status pekerjaan dan tingkat kepatuhan minum obat tidak berhubungan dengan kualitas hidup ODHA. Sebaliknya, tingkat pendapatan, lama terdiagnosa, lama terapi ART, tingkat dukungan keluarga, tingkat stigma dan tingkat depresi berhubungan dengan kualitas hidup ODHA. Berdasarkan hasil tersebut, maka diperlukan upaya yang terfokus pada permasalahan kesehatan mental yang bertujuan untuk meningkatkan kualitas hidup ODHA yang didampingi tanpa membeda-bedakan karakteristik ODHA sehingga seluruhnya dapat berpartisipasi tanpa syarat apapun. Upaya pengembangan program promosi kesehatan untuk menurunkan stigma juga perlu dilakukan dengan tujuan mengubah sikap individu terhadap ODHA melalui kampanye media yang mempromosikan toleransi dan kasih sayang. Pelatihan kepada orangtua juga dapat membantu mengurangi stigma terkait HIV dan isolasi sosial, hal ini dapat membantu orangtua mengajarkan anakanaknya cara berinteraksi dengan ODHA sekaligus mengupayakan pencegahan terhadap risiko HIV/AIDS.

\section{Ucapan Terima Kasih}

Ucapan terima kasih penulis sampaikan kepada responden dan pengurus Yayasan Sehat Peduli Kasih, Kota Semarang yang telah membantu dalam penelitian ini.

\section{Daftar Pustaka}

1. HIV.gov. 2020. What Are HIV and AIDS ? [Online]. Available from : https://www.hiv. gov/hivbasics/overview/about-hiv-and-aids/ what-are-hiv-and-aids.

2. UNAIDS. 2019. UNAIDS Data 2019. [Online]. Available from :https://www. unaids.org/en/resources/documents/2019/20 19-UNAIDS-data.

3. Kementerian Kesehatan RI. 2019. Data dan Informasi Profil Kesehatan Indonesia 2019. [Online] Available from: https://pusdatin. kemkes.go.id/resources/download/pusdatin/ profil-kesehatan-indonesia/Profil-

Kesehatan-Indonesia-2019.pdf.

4. Dinas Kesehatan Kota Semarang. 2018. Profil Kesehatan Kota Semarang 2018. [Online] Available from: https://dinkes. semarangkota.go.id/content/menu/7.

5. Kusuma, H. 2016. Faktor-faktor yang mempengaruhi kualitas hidup pasien HIV/AIDS yang menjalani perawatan di RSUPN Cipto Mangunkusumo Jakarta. 
Media Medika Muda 1(2) [online]. Available from : https://ejournal2.undip. ac.id/index.php/mmm/article/view/2602.

6. Tobiasz-Adamczyk, B. 2013. Health-related quality of life in cardiovascular patients. Milan : Springer.

7. CDC. 2018. Health-related quality of life (HRQOL). [Online] Available from: https://www.cdc.gov/hrqol/concept.htm.

8. Hapsari, Elyana. 2016. Hubungan tingkat depresi dengan kualitas hidup pasien HIV/AIDS di RSUP Dr. Kariadi Semarang. Jurnal Kedokteran Diponegoro, 5(4) [online]. Available from : http://ejournals1. undip.ac.id/index.php/medico.

9. Wiyati, TGK. 2019. Hubungan antara lama terdiagnosa dengan kualitas hidup orang dengan HIV/AIDS di Yayasan Victory Plus Tahun 2019 [online]. Available from: http://eprints.poltekkesjogja.ac.id/2269/1/N ASKAH\%20SKRIPSI.pdf.

10. Mariany, BS. 2019. Stigma, Depresi dan kualitas hidup penderita HIV : Studi pada komunitas lelaki seks dengan lelaki di Pematangsiantar. Berita Kedokteran Masyarakat, 35(4) [online]. Available from :https://jurnal.ugm.ac.id/bkm/article/vi ew/42808.

11. Banna, T. 2019. Kualitas Hidup Orang Dengan HIV dan AIDS (ODHA) ditinjau dari kepatuhan minum Obat Antiretroviral (ARV). Wellness Health Magazine, 1(1) [online]. Available from: https://wellness. journalpress.id/wellness/article/view/w1101.

12. Mardia. 2017. Kualitas hidup ODHA di Kota Surakarta. Berita Kedokteran Masyarakat, 33(1) [online]. Available from : https://jurnal.ugm.ac.id/bkm/article/ view/12563/15697.
13. Rokhani. 2018. Kualitas Hidup ODHA setelah 10 tahun dengan HIV/AIDS. Prosiding Seminar Nasional Unimus [online]. Available from: http://prosiding. unimus.ac.id/index.php/semnas/article/view/ 30.

14. Zainudin, H. 2016. faktor-faktor yang mempengaruhi kualitas hidup orang dengan HIV/AIDS (ODHA) di LSM Perjuangan Kupang. CHMK Health Journal [online]. Available from : https://www. neliti.com/id/publications/316304/faktorfaktor-yang-mempengaruhi-kualitas-hidupodha-di-lsm-perjuangan-kota-kupang.

15. Carsita, W. 2019. Kualitas hidup ODHA di Kecamatan Bongas. Jurnal Keperawatan Profesional, 7(2) [online] Available from: https://ejournal.unuja.ac.id/index.php/jkp/art icle/view/603.

16. Saputra, W. 2019. Hubungan dukungan emosional keluarga terhadap kualitas hidup penderita HIV/AIDS di Yayasan Victory Plus Yogyakarta [online]. Available from : http://digilib2.unisayogya.ac.id/xm lui/handle/123456789/436.

17. Handayani, F. 2017. Faktor yang mempengaruhi kualitas hidup orang dengan HIV/AIDS di Kota Kupang. Berita Kedokteran Masyarakat, 3(11) [online]. Available from: https://jurnal.ugm.ac.id/ bkm/article/view/25856.

18. Suryana, K. 2019. Factors associated with adherence to Anti-Retroviral Therapy among people living with HIV/AIDS at Wangaya Hospital in Denpasar, Bali, Indonesia: A Cross-Sectional Study. HIV'AIDS-Research and Palliative Care, 11 [online]. Available from : http://erepo.unud. ac.id/id/eprint/34907/1/e4b0136219f81bfa9 2676facd86d4060.pdf. 
19. Lubis, L. 2016. Hubungan stigma, depresi dan kelelahan dengan kualitas hidup pasien HIV/AIDS di Klinik Veteran Medan. Idea Nursing Journal, 7(1) [online]. Available at : http://jurnal.unsyiah.ac.id/ INJ/article/view/6460.

20. Jiang, H. 2019. Negative life events and major depressive disorder among HIVPositive Individuals in Guangdong, China : A cross-sectional study. Medicine (Baltimore), 98(37) [online]. Available from:https://journals.lww.com/mdjournal/Fu 1lText/2019/09130/Negativelife_event_and_ major_depressive_disorder.63.aspx. 